\author{
DOI: $10.31866 / 2617-2674.3 .2 .2020 .217640$ \\ UDC 303.627-028.23:654.197:004.77
}

\title{
VIDEO INTERVIEW IN CONTEMPORARY MEDIA SPACE
}

\author{
Oleksandr Butko ${ }^{1 a}$, Kseniia Semenova ${ }^{2 a}$
}

${ }^{1}$ Honoured Journalist of Ukraine, Associate Professor of the Television Journalism and Acting Department; e-mail: butko2016@ukr.net; ORCID: 0000-0002-5054-284X

2 Master's Student, Television Journalism and Acting Department; e-mail: semenovakseniia98@gmail.com; ORCID: 0000-0001-9650-4147

${ }^{a}$ Kyiv National University of Culture and Arts, Kyiv, Ukraine

\section{Keywords:}

interview;

television;

journalism;

media;

interviewer;

YouTube

\begin{abstract}
The purpose of the research is peculiarities of a video interview in the contemporary media world. Research Methodology. To research the peculiarities of the interview we applied the following methods: analysis and synthesis (analyzed the peculiarities of preparation, running interview and its impact on the modern audience), comparative methods (compared peculiarities of an interview in programs of various directions on television and the YouTube platform, and provides comparative aspects of researches in respect of researched genre), systematization (processing of information was generalized to a consolidated conclusion). The scientific novelty means that for the first time the comparative analysis regarding the application of video interview in Ukrainian television space and on the Internet, compared theoretical researches and practical application of this genre on-air, systematized certain professional rules and taboo journalists (anchors). Conclusions. During the research of peculiarities of video interview in contemporary media space we analyzed the works of media scholars, provided and analyzed techniques of working on air, studied the examples of the application of interview in modern television. On the basis of information researched, we consolidated the conclusions in respect of the impact of the interview on the audience.
\end{abstract}

For citation:

Butko, O. and Semenova, K. (2020). Video interview in contemporary media space. Bulletin of Kyiv National University of Culture and Arts. Series in Audiovisual Arts and Production, 3(2), pp.190-196.

\section{Problem Statement}

An interview is the most common and most popular genre on television. It should be noted that the genre of interviews is developing dynamically in volume and depth, it is used in information, journalism, science, cognitive, entertainment and even music programs. In recent decades, many programs based solely on interviews have appeared on the air. It is safe to say that interviews are of interest to all segments of the population. 
Naturally, the interviewers themselves journalists, presenters, actors, lately even politicians - also attract attention.

\section{Recent research and publications analysis}

The study analyzed Internet sources, which used information on the topic of our study, as well as analyzed the scientific materials of media professionals, namely: S. Ilchenko, who successfully described the professional rules of how to run an interview. Scientist M. Muratov gives the basic rules of how not to run an interview.

\section{Purpose of the article}

The purpose of the research is to explore the features of video interviews in the modern media world. We tried to determine the qualities that an interviewer should have; establish the stages of preparation and factors of successful interviewing; highlight practical advice from well-known journalists and anchors.

\section{Main research material}

Many modern television projects are based on interviews. Therefore, to succeed you need to understand how to use this genre.

The interview is meaningful mainly in two cases:

1. The guest is more educated than a TV journalist.

2. The outlined question can interest a considerable audience.

Researchers of this genre give (depending on the volume, form or content) different classifications of interviews: informational, operational, cognitive, portrait, investigative, entertaining, provocative, blitz or flash interviews, conversations...
N. Simonina (2012, p.181) is convinced that this genre includes synchrony.

But we believe Professor Michael Haller (2008, p.105) divided the interview into types the most accurately:

- a fairly short interview that was about one event or problem with a person;

- an interview that focuses on a specific issue and at the same time on a person, thus revealing a certain relationship between the actions of the person being interviewed;

- one-person interview.

Let's focus on the aspects of the work of a television journalist (anchor) on the second and third types of interviews (according to M. Haller's classification), because "quite short" may not require the interviewer to carefully prepare, deep professional knowledge, mastery of psychological techniques.

Many consider them perhaps the most difficult type of journalistic work, referring to the estimates by American researchers who believe that interviews "eat" 80 to 90 per cent of journalists' working time (Lukina, 2003).

The majority is dedicated to the preparatory period. This is choosing a topic, character, location (if it is extracurricular shooting), developing a preliminary script for the conversation or formulating questions, participating in the organization of the filming process, and finally an agreement with the object of the interview, which is also a difficult task. Well-known TV anchor D. Hordon (2015) admitted at a meeting with students of Kyiv National University of Culture and Arts: "Sometimes I spend years looking for approaches to my characters. Inviting them to talk, I even resort to unusual actions. I find my arguments for everyone, sometimes I offer an interview fee". 
In television practice, there is a certain scheme of work of the presenter for the interview:

Introduction. The journalist introduces the interlocutor, introduces the viewer to him. It is necessary to indicate the name, patronymic, surname, full title of the interlocutor (during the conversation, this information is usually duplicated several times by captions). Now the hosts often use the reception, when at the beginning of the summary of the topic or problem, and only then announces the guest.

Main part. Dialogue between the anchor and the interviewee. It is possible to use documentary records that the hero comments on.

Conclusion. There are two types: the author's (the journalist summarizes the conversation), the interlocutor (the conclusion is the last answer, which puts a logical end to the conversation).

In the end, the presenter usually reminds who the conversation took place with.

The topic of the interview, as well as its character, can be both an editorial task and the interviewer's own choice. Moreover, it makes no sense to argue about what to start from: from the topic or the main character. It is important that the topic was relevant, topical, at least informative, and the character - competent and interesting to a large audience.

TV anchor Yu. Lytvynenko, who has prepared several large series of interviews during her career and became famous in the program "Out of Sight", notes: Every time we realized that we need to go to the holy of holies - a private life that most people do not like to advertise... I think the heroes of the program were revealed to us because we have always been tolerant, did not cross the border. Because for both doctors and journalists, the main rule should be: no harm!” (2013).
For a TV journalist or presenter to prepare for an interview meticulously, it is necessary to study the biography thoroughly, creation path (if this is a star), political life (if this is a politician) and watch many programs with the interviewee. The next stage is to think in detail about the probable questions to the character. It should be borne in mind that pre-prepared questions will not always be on the air, because the topic of conversation may develop depending on the answers heard.

It is worth agreeing with the opinion of the well-known interviewer O. Drozdov (2015), who believes: "Literal blanks are a manifestation of unprofessionalism. I repeatedly watched my colleagues panic as soon as the conversation went as planned. I can't have such a priori. The journalist must know his benchmarks in the conversation, and everything else must create a live broadcast. This, in fact, is the magic of this profession".

The interviewer must be ready to keep the logic, the sequence of the conversation, not forgetting, however, some basic positions from the editorial task or from their blanks. If they get lost, lose control of the conversation, the result can be quite sad.

Perhaps the most important thing is to gain the character's affection for themselves, to talk, to stir them up. Therefore, the beginning is extremely important in the interview, i.e. the first question on which the further conversation depends. Experienced interviewers usually start of the ordinary, non-trivial, as if forcing the interlocutor to immediately turn on the brain at full capacity, to mobilize. The most striking example, namely on information television, is Max Nazarov - NASH TV channel. From the first second, he asks his guests nonstandard and relevant questions that immediately lead them to a dead end. 
An on-screen interview should always look like a casual conversation between two people. A conversation in which one person (specialist) is more informed than another. And even if the journalist (anchor) is brilliantly prepared for the conversation, well acquainted with the topics, when talking they must be as restrained as possible in demonstrating their knowledge. They listen to the facts, observe the interlocutor, their facial expressions, gestures, intonation and, of course, can draw certain conclusions and influence the course of communication. But the conversation should not turn into an interrogation, the interviewer should minimize their own influence on the content of the respondent's answers to ensure the adequate perception of what the audience heard.

Many professionals give practical professional advice on how to and should not conduct interviews. We will not reinvent anything, but only list those that, in our opinion, are appropriate and useful.

So, as desired:

- Interview from the point of view of inquisitive ignoramuses (be calm, objective and unobtrusive).

- Ask clear, concise, simple and specific questions.

- Avoid asking several questions at once, because the newsmaker often remembers only the last question or chooses the most convenient for himself, the rest - just ignores.

- Do not be held hostage to an interview plan (improvised).

- Avoid questions that have multiple meanings. Stop the conversation when the guest gives inaccurate answers.

- Communicate with a senior official on an equal footing.

- The main question is to speak again (perhaps some new details will be mentioned) (Ilchenko, 2016, p.24).
The list of rules is about the same, which cannot be done during the interview:

- You can't ask yes-or-no questions there is a risk of getting a "yes" or "no" answer (and getting stuck).

- Avoid the "flight of information" in the question (additional, unnecessary details). In other words - to prevent the divergence of opinions.

- Do not ask hypothetical questions ("What will you do if you are evicted?").

- You cannot link to unverified sources only to documents.

- The facilitator should keep his or her judgments unspoken in any situation.

- Each question asked should be separate from each other.

- Do not ask rhetorical questions (those the interlocutor cannot answer) (Muratov, 2007, p.111).

The modern media space is filled with various interviews. In recent years, they have become an integral part of almost every program on almost all TV channels, both Ukrainian and global.

Thanks to the interviews, many anchors have become really top interviewers, which they are either afraid of or want to get into a conversation with. In Ukraine, for example, such are Dmytro Hordon, Petro Maha, Kateryna Osadcha, Yevhenii Kyselov, Yuliia Lytvynenko, Ostap Drozdov, Maks Nazarov, etc.

Interviews are becoming very popular on YouTube. The most popular Ukrainian program of this genre on the hosting is "ZE INTERVIEWER", hosted by Anatolii Yatsechko (pseudonym Anatolii Anatolich). He also works on television in the morning show, but there he does not have as many opportunities as there are on YouTube. He interviews famous artists, politicians, actors and businessmen.

Analyzing interviewers in the modern media space, it is necessary to focus 
on the Russian blogger Yuri Dud, who has a multimillion-dollar audience. He specializes in "hot" topics and does not restrain himself in his statements, says and asks everything he wants. Millions of views of his video break all stereotypes and rules about interviews. Dud was even invited to appear on television, but he refused because he was not ready to work under a certain "framework" and script.

Note that most programs and television interviewers are now available on the Internet. After all, not only the current generations but also our descendants will be able to see and hear our outstanding and not very contemporaries with a few clicks on the keyboard or touch on the screens of terminals, evaluate their worldview, get reliable evidence of events that will become ancient history.

\section{Conclusions}

All of the above allows us to emphasize that the interview will always be one of the most popular genres of television journalism in the contemporary media space. It is interesting for viewers to watch outstanding personalities, their creative way; behind the political vicissitudes to hear different, sometimes sensational assessments of what is happening today.

The interviewer faces many important tasks. Understanding the topic, thinking through questions, a deep understanding of all the nuances of the conversation. The ability to always listen carefully to the interlocutor, to react instantly to turns in the conversation, the willingness to confirm the views of the hero or to express an alternative view. Hearing is perhaps the most important professional trait of an interviewer. During the conversation, the interviewer should not disperse and interrupt the semantic thought. The interviewer must be able to improvise, appeal to certain reliable facts. Not every experienced TV journalist can talk to a guest so that he opens up to the audience from an unexpected angle.

During the writing of the scientific article the works of researchers, creative works of famous interviewers and their practical experience were analyzed, systematized and generalized.

\section{REFERENCES}

Hordon, D., 2015. Moi interviu tse ne prosto televiziina prohrama, tse naichesnishyi pidruchnyk istorii [My Interview is not just a TV program, but the best handler of history]. [online] Available at: <http://knukim.edu.ua/dmitro-gordon-moyi-interv-yu-tse-ne-prosto-televiziyna-programatse-naychesnishiy-pidruchnik-istoriyi/> [Accessed 29 April 2020].

Il'chenko, S.N., 2016. Interv'ju v zhurnalistike: kak jeto delaetsja [Interview in journalism: how it is done]. St. Petersburg.

Khaler, M., 2008. Interviu [Interview]. Kyiv: Akademiia Ukraïnskoï Presy, Tsentr Vilnoï Presy. Lukina, M., 2003. Tehnologija interv'ju [Interview technology]. Moscow: Aspekt Press. [online] Available at: <http://evartist.narod.ru/text5/36.htm> [Accessed 24 April 2020].

Muratov, S., 2007. Televizionnoe obshhenie $v$ kadre i za kadrom [Television communication in and behind the scenes]. Moscow: Aspekt Press.

Samchenko, V., 2013. Yuliia Lytvynenko: Ukrainskym bude telebachennia z ukrainskymy veduchymy [Yulia Lytvynenko: Television with Ukrainian presenters will be Ukrainian]. Ukraina 
Moloda, [online] 140. Available at: <https://www.umoloda.kiev.ua/number/2340/211/83242/> [Accessed 29 April 2020].

Samchenko, V., 2015. Veduchyi Ostap Drozdov: "Khto prahne obiektyvnosti - viddaite "vati" polovynu efiriv" [Host Ostap Drozdov: "Who seeks objectivity - give" cotton "half of the air"]. Detektor media. [online] 16 May 2015. Available at: <https://detector.media/withoutsection/ article/107162/2015-05-16-veduchii-ostap-drozdov-khto-pragne-obektivnosti-viddaite-vatipolovinu-efiriv//> [Accessed 29 April 2020].

Symonina, N., 2012. Klasyfikatsiia suchasnoho televiziinoho interviu [Classification of modern television interviews]. Naukovyi visnyk Uzhhorodskoho universytetu: Seriia: Filolohiia. Sotsialni komunikatsii, [online] 27. Available at: <https://dspace.uzhnu.edu.ua/jspui/bitstream/ lib/3874/1/КЛАСИФІКАЦІЯ\%20СУЧАСНОГО\%20ТЕЛЕВІЗІЙНОГО\%20ІНТЕРВ'Ю.pdf> [Accessed 24 April 2020].

\title{
ВІДЕОІНТЕРВ'Ю В СУЧАСНОМУ МЕДІЙНОМУ ПРОСТОРІ
}

\section{Олександр Бутко1а ${ }^{1}$ Ксенія Семенова²a}

\author{
${ }^{1}$ заслужений журналіст України, доцент кафедри тележурналістики та майстерності актора; \\ e-mail: butko2016@ukr.net; ORCID: 0000-0002-5054-284X \\ ${ }^{2}$ магістрант кафедри тележурналістики та майстерності актора; \\ e-mail: semenovakseniia98@gmail.com; ORCID: 0000-0001-9650-4147 \\ а Київський національний університет культури і мистецтв, Київ, Україна
}

\begin{abstract}
Анотація
Мета дослідження - дослідити особливості відеоінтерв'ю в сучасному медіасвіті. Методологія дослідження. Для дослідження особливостей інтерв'ю було застосовано такі методи: аналіз та синтез (проаналізовано особливості підготовки, ведення інтерв'ю та його вплив на сучасну аудиторію), порівняльний метод (порівнювалися особливості інтерв'ю у програмах різноманітного спрямування на телебаченні і платформі YouTube, а також наведено порівняльні аспекти науковців щодо досліджуваного жанру), систематизація (обробка інформації зведена до загального висновку). Наукова новизна полягає у тому, що уперше проведено порівняльний аналіз щодо використання відеоінтерв'ю в українському телевізійному просторі та в Інтернеті, зіставлені теоретичні дослідження і практичне застосування цього жанру в ефірі, систематизовано певні професійні правила і табу для журналістів (ведучих). Висновки. Під час дослідження особливостей відеоінтерв'ю в сучасному медіапросторі було проаналізовано наукові праці науковців-медійників, наведені та схарактеризовані засоби роботи в ефірі, вивчено приклади використання інтерв'ю на сучасному телебаченні. На основі досліджуваної інформації виведено підсумки щодо впливу інтерв'ю на аудиторію.
\end{abstract}

Ключові слова: інтерв'ю; телебачення; журналістика; медіа; інтерв'юер; YouTube 


\title{
ВИДЕОИНТЕРВЬЮ В СОВРЕМЕННОМ МЕДИЙНОМ ПРОСТРАНСТВЕ
}

\author{
Александр Бутко ${ }^{1 a}$, Ксения Семенова $^{2 a}$ \\ 1 заслуженный журналист Украины, доцент кафедры тележурналистики и мастерства актера; \\ e-mail: butko2016@ukr.net; ORCID: 0000-0002-5054-284X \\ ${ }^{2}$ магистрант кафедры тележурналистики и мастерства актера; \\ e-mail: semenovakseniia98@gmail.com; ORCID: 0000-0001-9650-4147 \\ а Киевский национальный университет культуры и искусств, Киев, Украина
}

\begin{abstract}
Аннотация
Цель исследования - исследовать особенности видеоинтервью в современном медиамире. Методология исследования. Для исследования особенностей интервью были применены следующие методы: анализ и синтез (проанализированы особенности подготовки, ведения интервью и его влияние на современную аудиторию), сравнительный метод (сравнивались особенности интервью в программах различного направления на телевидении и платформе YouTube, а также приведены сравнительные аспекты ученых относительно исследуемого жанра), систематизация (обработка информации сведена к общему выводу). Научная новизна заключается в том, что впервые проведен сравнительный анализ по использованию видеоинтервью в украинском телевизионном пространстве и в Интернете, сопоставлены теоретические исследования и практическое применение этого жанра в эфире, систематизированы определенные профессиональные правила и табу для журналистов (ведущих). Выводы. Во время исследования особенностей видеоинтервью в современном медиапространстве были проанализированы научные труды ученых-медийщиков, приведены и охарактеризованы приемы работы в эфире, изучены примеры использования интервью на современном телевидении. На основе исследуемой информации выведены итоги по влиянию интервью на аудиторию.
\end{abstract}

Ключевые слова: интервью; телевидение; журналистика; медиа; интервьюер; YouTube 